\title{
Cladosporium cladosporioides from the perspectives of medical and biotechnological approaches
}

\author{
Manaf AlMatar ${ }^{1} \cdot$ Essam A. Makky $^{2}$
}

Received: 2 March 2015/Accepted: 16 June 2015/Published online: 31 December 2015

(C) The Author(s) 2015. This article is published with open access at Springerlink.com

\begin{abstract}
Fungi are important natural product sources that have enormous potential for the production of novel compounds for use in pharmacology, agricultural applications and industry. Compared with other natural sources such as plants, fungi are highly diverse but understudied. However, research on Cladosporium cladosporioides revealed the existence of bioactive products such as p-methylbenzoic acid, ergosterol peroxide (EP) and calphostin $\mathrm{C}$ as well as enzymes including pectin methylesterase (PME), polygalacturonase (PG) and chlorpyrifos hydrolase. p-Methylbenzoic acid has ability to synthesise 1,5-benzodiazepine and its derivatives, polyethylene terephthalate and eicosapentaenoic acid. EP has anticancer, antiangiogenic, antibacterial, anti-oxidative and immunosuppressive properties. Calphostin $\mathrm{C}$ inhibits protein kinase $\mathrm{C}$ (PKC) by inactivating both PKC-epsilon and PKC-alpha. In addition, calphostin $\mathrm{C}$ stimulates apoptosis in WEHI231 cells and vascular smooth muscle cells. Based on the stimulation of endoplasmic reticulum stress in some types of cancer, calphostin $\mathrm{C}$ has also been evaluated as a potential photodynamic therapeutic agent. Methylesterase (PME) and PG have garnered attention because of their usage in the food processing industry and significant physiological function in plants. Chlorpyrifos, a human,
\end{abstract}

Manaf AlMatar

manafmatar19@gmail.com; manafmatar@yahoo.com

1 Department of Biotechnology, Institute of Natural and Applied Sciences (Fen Bilimleri Enstitüsü), Cukurova University, Rectorate 01330 Balcali, Adana, Turkey

2 Department of Biotechnology, Faculty of Industrial Sciences and Technology, Universiti Malaysia Pahang (UMP), 26300 Gambang, Kuantan, Malaysia animal and plant toxin, can be degraded and eliminated by chlorpyrifos hydrolase.

Keywords Calphostin $(\mathrm{C}) \cdot$ Chlorpyrifos $\cdot$ Cladosporium cladosporioides . Ergosterol peroxide (EP) .

p-Methylbenzoic acid · Pectin methylesterase (PME) .

Polygalacturonase (PG)

\section{Introduction}

The genus Cladosporium, identified by Link for the first time in 1815 , is characterised by the absence of a sexual proliferation phase; therefore, it is classified into the Fungi Imperfecti (Deuteromycota) group. This genus belongs to the mitosporic Ascomycotic phylum, subphylum Pezizomycota, class Dothideomycetes, family Mycosphaerellaceae and contains approximately 500 species (De Hoog et al. 1995; Okada et al. 1996). Cladosporium, species are most frequently found in outdoor and indoor environments, spoiled organic matter and are considered as food important contaminants (Dixon and Polak-Wyss 1991; De Hoog et al. 2000; San-Martin et al. 2005). Additionally, some Cladosporium spp. can develop even on the surface of glass fibres and inside water pipes (Macher 1999; Johanning 1999). These fungi can utilise different growth substrates, such as, wood plants, dead plants, food, soil, straw and textiles (Tasić and Miladinović-Tasić 2007). Several species of this genus have been associated with fish diseases (Otto 2000). The common ancestor has been identified for only 15 species of Cladosporium. The most isolated species are Cladosporium sphaerospermum, Cladosporium cladosporioides, Cladosporium herbarum and Cladosporium elatum (De Hoog et al. 1995; Masclaux et al. 1995). In contrast, many species of Cladosporium are 
also able to produce some secondary metabolites such as, antibiotics which are inhibitors of Bacillus subtilis, Escherichia coli and Candida albicans (Gallo et al. 2004). Furthermore, some Cladosporium species are efficient biological insecticides, particularly against insects that have developed resistance to chemical insecticides (AbdelBaky and Abdel-Salam 2003).

Cladosporium cladosporioides normally grows on potato-dextrose agar (PDA) medium and generates onecelled conidia (spores). It is recognised by the formation of $3-\mathrm{cm}$ diameter colonies, which are either (the colonies are either) olive-green or brown basal side (Krogh 1989; Tasić and Miladinović-Tasić 2007). In this review, we critically summarise the medical and industrial usage of bioactive compounds and enzymes derived from C. cladosporioides.

\section{Bioactive metabolites from Cladosporium cladosporioides}

\section{p-Methylbenzoic acid}

p-Methylbenzoic acid (Fig. 1), known as p-toluic acid, was extracted from $C$. cladosporioides an isolate from marine sponge and later identified using spectroscopic methods (San-Martin et al. 2005). p-Methylbenzoic acid promotes the synthesis of 1,5-benzodiazepine and its derivatives, which are active compounds against diverse targets such as interleukin converting enzymes (ICE), potassium blockers $\left(\mathrm{I}_{\mathrm{k}}\right)$ and peptide hormones (CCK) (Herpin et al. 2000; Varala et al. 2007). Benzodiazepines are widely used as antianxiety, anticonvulsant, anti-depressive, anti-inflammatory agents, analgesics and sedatives (Tsoleridis et al. 2008). Benzodiazepines have a variety of activities including antiulcer, antileukaemic, vasopressin antagonist, antiplatelet and endothelial antagonist and relief of skeletal muscle joint pain (Kumar and Joshi 2007; Aasth et al. 2013). Benzodiazepines are also used as fibre dyes and are used to produce fused ring compounds such as oxadiazolo-, triazolo-, oxazino- or furano benzodiazepines (Wu et al. 2006; Aasth et al. 2013). Initially used to yield

Fig. 1 p-Toluic acid structure

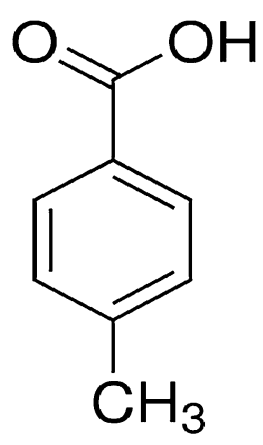

polyethylene terephthalate (PET) via condensation polymerisation with ethylene glycol, p-methylbenzoic acid is an intermediate in the production of terephthalic acid (Speight 1999). PET is widely used commercially and has one of the highest manufactured tonnages of all polymer products in the world (Jankauskaite et al. 2008). PET is used to produce fabrics, fibres and textiles. In addition, PET has progressively dominated the bottle market for bottled water and carbonated soft drinks as well as food containers and packaging materials. These days, PET is increasingly being used to produce fibre strengthened composite (Giles and Bain 2001; Vakili and Fard 2010).

Based on studies, Shirasaka et al. (2005) demonstrated that p-methylbenzoic affect fatty acid composition by increasing eicosapentaenoic acid (EPA) production. EPA, a (n-3) long-chain polyunsaturated fatty acid (PUFA), serves as the phospholipid acyl group in membrane-bound organisms ranging from bacteria to humans. EPA contributes to membrane organisation, cell division and resistance to oxidative stress at low temperatures in psychrophiles and marine bacteria (Nishida et al. 2006; Okuyama et al. 2007; Kawamoto et al. 2009).

Consuming EPA, one of the primary v-3 fatty acids in fish oils, has been demonstrated to be beneficial in several experimental and clinical studies. A standard dose of EPA inhibits tumour growth-induced lipolysis and muscle protein degradation, possibly by suppressing the cytokine IL-6 and reducing a tumour-specific product that is a proteolysis-inducing factor (PIF) EPA improved prolonged survival, enhanced weight maintenance, ameliorated food intake and reduced protein degradation without effecting protein synthesis. These observations indicate that EPA may be useful for the clinical management of malignancy patients (Beck et al. 1991; Babcock et al. 2000a). The American Heart Association (AHA) recommends that patients suffering from heart diseases such as coronary heart disease should supplement their diet with (1 g) EPA and docosahexaenoic acid (DHA) daily. The AHA also recommends that healthy adults consume one serving of fish at least two times per week (Manhiani et al. 2009). Anti-inflammatory activity has specifically been demonstrated for EPA, but not for all v-3 fatty acids. However, regioisomeric mixtures of EPA and epoxydocosapentaenoic acid (EDP) appear to be highly efficient for reducing inflammatory pain (Beck et al. 1991; Inceoglu et al. 2011). Doses of 1.25-2.5 g/kg body weight have been observed to produce the optimal effect when using EPA (Babcock et al. 2000b).

\section{Ergosterol peroxide (EP)}

Ergosterol peroxide (EP) (Fig. 2), a bioactive compound, has been extracted from $C$. cladosporioides obtained from 


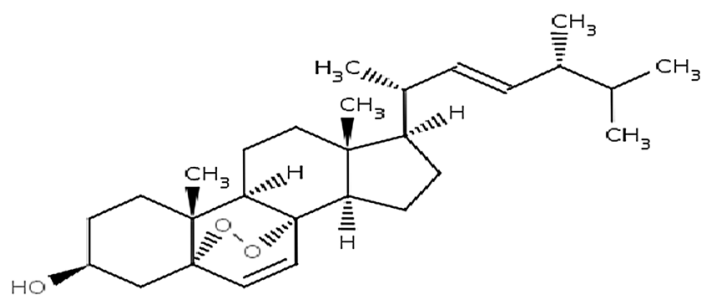

Fig. 2 Ergosterol peroxide (EP) structure

a marine sponge using spectroscopic methods (San-Martin et al. 2005). EP isolated from $C$. cladosporioides has not been examined against various types of diseases. However, EP isolated from different organisms ranging from fungi to plants has been reported to have anticancer, antiangiogenic, antibacterial, anti-oxidative and immunosuppressive properties (Rhee et al. 2012). EP, known as pro-vitamin $\mathrm{D}_{2}$, contributes to the prevention of colon and prostate cancer (Kobori et al. 2007). EP inhibits phorbol-12-myristate 13-acetate (TPA), TPA-induced inflammation and tumour promotion in mice (Kobori et al. 2007). EP also inhibits the growth of certain cancer cells, stimulates apoptosis in HL60 human leukaemia cells, reduces lipid peroxidation in rat liver microsomes and represses the production of mitogen stimulated mouse and human lymphocytes (Yasukawa et al. 1994; Fujimoto et al. 1994; Bok et al. 1999; Yaoita et al. 2002; Guyton et al. 2003; Kuo et al. 2003; Takei et al. 2005; Prompiboon et al. 2008).

According to Rhee et al. (2012), nontoxic concentrations of EP suppress the DNA-binding activity, phosphorylation, nuclear trans-localisation of signal transducer and activator of transcription 3 (STAT3) in U266 cells. EP inhibits the phosphorylation of the upstream kinase, Janus kinase 2 (JAK2) and other tyrosine kinase family members, i.e., Src homology region 2 domain-containing phosphatase-1 (SHP-1). SHP-1 protein and mRNA levels are increased by EP; conversely, silencing the SHP-1 gene abrogates EPmediated STAT3 inhibition (Rhee et al. 2012). Furthermore, cellular and protein levels of vascular endothelial growth factor (VEGF), a STAT3 target gene, are decreased by EP. Female BALB/c athymic nude mice inoculated with U266 cells have significantly reduced tumour growth when treated with EP (Rhee et al. 2012). Additionally, EP treatment reduced STAT3 and CD34 expression in tumours (Rhee et al. 2012). It has been demonstrated that EP suppresses LPS-induced inflammatory responses by inhibiting $\mathrm{NF}-\mathrm{kB}$ and $\mathrm{C} / \mathrm{EBPb}$ transcriptional activity and phosphorylation of MAP kinases (MAPKs) (Kobori et al. 2007). EP further suppresses cell growth and STAT1-mediated inflammatory responses by altering the redox status in HT29 cells (Kobori et al. 2007).

EP is a highly efficient antimicrobial agent against the Gram-positive pyogenic bacterium, Staphylococcus aureus, with an MIC value of $50 \mathrm{mg} / \mathrm{ml}$ (Huong et al. 2010; San-Martin et al. 2005). EP also exhibits cytotoxic activity against RD cancer cells with an $\mathrm{IC}_{50}$ of $4.6 \mathrm{mg} / \mathrm{ml}$ (Huong et al. 2010). Recent studies indicate oncogene and tumour suppressor gene expression is controlled by RNAs referred to as microRNAs (miRNAs) (Calin and Croce 2006; Lee et al. 2007). The expression of certain microRNAs (miRNAs) is increased in cancer and drug-resistant cells (Zheng et al. 2010). EP effectively stimulated death in miR-378 cells at low concentrations. Therefore, EP may be a promising novel therapeutic agent against drug-resistant tumour cell (Wu et al. 2012).

\section{Calphostin (C)}

Calphostin C (Fig. 3), isolated from C. cladosporioides culture broth, inhibits protein kinase $\mathrm{C}$ (PKC) by inactivating both $\mathrm{PKC}$-epsilon $[\mathrm{a} \mathrm{Ca}(2+)$-independent novel isoform] and $\mathrm{PKC}$-alpha [a $\mathrm{Ca}(2+)$-dependent conventional isoform] and exhibits cytotoxic activity against various tumour cells (Rotenberg et al. 1995). A $500 \mathrm{nM}$ calphostin C concentration was used to test a series of N-terminal-truncated bovine PKC-alpha mutants expressed in Saccharomyces. This concentration was active against proteins with up to 91 amino acid (aa) deletions from the amino terminus (ND91), while only $20 \%$ inhibition occurred against a mutant protein truncated by 140 aa (ND140). Therefore, the amino acid (aa) sequence from 92 to 140 contains the structural element of PKC-alpha that is suppressed by calphostin C (Kobayashi et al. 1989; Rotenberg et al. 1995). Calphostin C reduces cancer cell lung colonisation and adherence to the endothelium for both high and low metastatic sub-populations at sub-micromolar $\mathrm{IC}_{50}$ concentrations (Liu et al. 1992). At a $3 \mu \mathrm{M}$ concentration, calphostin $\mathrm{C}$ repressed ISO+ ionomycininduced cAMP and cGMP accretion by 80 and $78 \%$, respectively (Ogiwara et al. 1998). The effects of calphostin $\mathrm{C}$ in vitro have been assessed using $\varepsilon$-peptide, $\zeta$-peptide and Ac-MBP (4-14) as substrates (Ogiwara et al. 1998). The percent inhibition of Ac-MBP (4-14) phosphorylation was $58 \%$ at a $1 \mu \mathrm{M}$ calphostin $\mathrm{C}$<smiles></smiles>

Fig. 3 Calphostin (C) structure 
concentration. However, calphostin $\mathrm{C}$ reduced phosphorylation by 60 and $50 \%$ when $\varepsilon$-peptide and $\zeta$-peptide were used as substrates, respectively (Ogiwara et al. 1998).

WEHI-231 cells undergo apoptosis when calphostin $\mathrm{C}$ is used at a $250 \mathrm{nM}$ concentration (Chmura et al. 1996). The addition of calphostin $\mathrm{C}$ led to increased ceramide production compared with baseline levels and a simultaneous decrease in sphingomyelin; therefore, calphostin $\mathrm{C}$ synergistically acted with exogenous ceramide analogues to induce apoptosis (Chmura et al. 1996). These findings imply that the relationship between PKC activity and ceramide is antagonistic to the signalling events prior to apoptosis (Chmura et al. 1996). Potent inhibitors of phospholipase (PLDs) have an anti-apoptotic effect in vascular smooth muscle cells (VSMCs); however, PLD activity is suppressed by calphostin C, resulting in VSMC apoptosis. Calphostin $\mathrm{C}$ also increases microtubule disturbances, suggesting that calphostin $\mathrm{C}$ may be used to destabilise microtubule networks. Consequently, calphostin $\mathrm{C}$ induces VSMC apoptosis by inhibiting PLD activity followed by microtubule polymerisation (Zheng et al. 2004). The earliest calphostin $\mathrm{C}$ effect is the destruction of glycoprotein export from the endoplasmic reticulum (ER), accompanied by ER-originated vacuole creation. Vacuolisation of the ER is associated with ER stress response induction, which includes the activation of c-Jun N-terminal kinase, protein kinase R-like ER kinase and increased expression of CCAAT/enhancer binding protein homologous transcription factor (CHOP; GADD153). These effects indicate that ER stress is the result of calphostin $\mathrm{C}$ interaction with targets other than PKC (Kaul and Maltese 2009). Cell sensitivity to calphostin $\mathrm{C}$ decreased when CHOP expression was reduced, suggesting that calphostin $\mathrm{C}$ apoptosis induction via ER stress is due to the interruption of ER morphology and transport function. Because calphostin $\mathrm{C}$ can elicit ER stress, it has been evaluated as a potential photodynamic therapy agent against certain cancers (Kaul and Maltese 2009).

\section{Enzymes secreted by Cladosporium cladosporioides}

\section{Pectin methylesterase (PME) and polygalacturonase (PG)}

The pectinase enzymes PME and PG have been reported to be excreted by $C$. cladosporioides and were extracted using the Buescher and Furmanski procedure (Bastos et al. 2013). The ideal conditions to produce both PME and PG are after 10 days of incubation and precipitation with $\left(\mathrm{NH}_{4}\right)_{2} \mathrm{SO}_{4}$ and benzoate buffer at $\mathrm{pH} 4.0$ (Buescher and Furmanski 1978; Silva et al. 2008; Bastos et al. 2013). Pectinases, or pectinolytic enzymes, are found in plants, bacteria, insects and fungi and can be categorised into three main groups: pectinesterases, protopectinases and depolymerases. Pectin de-esterification catalysed by esterase enzymes leads to the removal of the metoxyl ester group. The degradation of insoluble protopectin is performed by protopectinases, resulting in highly polymerised soluble pectin. However, hydrolysis of the $\alpha(1 \rightarrow 4)$ glycosidic linkage in pectic acid is catalysed by depolymerases (Whitaker et al. 2003; Jayani et al. 2005; Gonzalez and Rosso 2011). PME (EC 3.1.1.11) is responsible for pectin degradation by catalysing the demethoxylation of the homogalacturonan chain of pectin to release methanol and acidic pectin (Micheli 2001). Pectin is a primary component of plant cell walls; therefore, PME can affect the integrity and rigidity of plant tissues. PG catalyses the hydrolytic cleavage of the polygalacturonic acid chain via the introduction of water across the oxygen bridge, releasing galacturonic acid as the main product (Kluskens et al. 2005).

Recently, pectinases have garnered attention due to their application in the food processing industry and critical role in plant physiology (Dixit et al. 2013). The main industrial purposes of pectinases are to extract and clarify fruit and vegetable juice (Alkorta et al. 1998). Pectin is responsible for the consistency and turbidity of juice, resulting in increased viscosity that prevents juice concentration, clarification and filtration. Pectin degradation is achieved by adding pectolytic enzymes leading to high juice yields by allowing additional clarification and filtering as well as reduced viscosity (Sarığlu et al. 2001; De Gregorio et al. 2002; Souza et al. 2003; Fernández-González et al. 2004; Ribeiro et al. 2010). Unicellular products, formed by the transformation of organised tissues into a suspension of intact cells, can be produced by pectinase enzymes (Kashyap et al. 2001). These products can be used in pulpy juices and nectars, baby foods, dairy products such as yogurt and puddings and protoplasts for diverse biotechnological applications (Kashyap et al. 2001). Vegetable oil extraction has been performed using pectinase enzymes. Oil yield and stability are improved after enzyme treatment and polyphenol and vitamin $\mathrm{E}$ content are increased, improving the oil's organoleptic quality (Kashyap et al. 2001; Hoondal et al. 2002; Iconomou et al. 2010). Pectolytic microorganisms are also used to ferment coffee beans, a process that removes the mucilage layer from the beans (Avallone et al. 2002). For example, a commercial enzyme product containing pectinase is applied to coffee beans to initiate fermentation (Pasha et al. 2013). Significantly, fermentation time has been reduced by using pectinase enzymes (Amorim and Amorim 1977; Silva et al. 2000; Kashyap et al. 2001; Serrat et al. 2002). Chocolate flavour is developed by cocoa fermentation, which is performed using pectinolytic enzymes (Schwan and Wheals 2004; Ouattara et al. 2010). Tea leaf fermentation has been 
accelerated and facilitated by treatment with pectic enzymes at a dose adjusted to avoid leaf damage (Carr 1985; Kashyap et al. 2001). Pectolytic enzymes which have fungal origin facilitate the wine fermentation process and improve the quality and diversification of products (Sieiro et al. 2012). During the winemaking extraction process, pectic enzymes facilitate filtration and intensify wine flavour and colour (Sieiro et al. 2012).

\section{Chlorpyrifos hydrolase}

Because of its use as a broad spectrum insecticide, chlorpyrifos ( $O, O$-diethyl $O$-(3,5,6-trichloro-2-pyridyl) phosphorothioate) has been widely restricted in some European countries and the United states as it is potentially toxic and persistent in the environment ( $\mathrm{Li}$ et al. 2007; Bhagobaty et al. 2006). 3,5,6-Trichloro-2-pyridinol (TCP) is a metabolite released from chlorpyrifos and chlorpyrifosmethyl during degradation (Xu et al. 2008; Anwar et al. 2009; Li et al. 2010). These compounds can be transported through the atmosphere and water and may transfer into soils and sediments, resulting in diffuse pollution (Harms et al. 2011). Oliver et al. (1999) demonstrated that chlorpyrifos is harmful to the respiratory system, central nervous system, cardiovascular system and reproductive system because of its highly potent toxicity. Their study was conducted in the United States at Columbia University in 263 pregnant females who were exposed to approximately to the same level of contamination. An acute relationship was observed between prenatal exposure to chlorpyrifos and low birth weight and smaller infant head size. Smaller head size is correlated with poor function and lower intelligence quotients (IQ). Chlorpyrifos' toxic effects extend to diverse types of arthropods including ladybird beetles, bees and parasitic wasps (Lee et al. 2012). Chlorpyrifos also affects birds and fish, leading to reduced nestling weight and morphologic distortions for birds as well as death for both organisms (NCAP 2000). In plants, prolonged chlorpyrifos exposure leads to delayed seedling emergence, abnormal cell division and fruit malformation (Bhagobaty et al. 2006). Moreover, public attention to potential human health risks, from exposure to chlorpyrifos residue on food, has increased due to the frequent use of chlorpyrifos in agriculture (Cochran et al. 1995; Yu et al. 2006). Consequently, it is necessary to develop methods to degrade and eliminate chlorpyrifos from the environment. Although several bacterial isolates have demonstrated the ability to degrade chlorpyrifos, there is limited information regarding chlorpyrifos elimination by fungi (Singh et al. 2004; Li et al. 2007; Xu et al. 2008; Anwar et al. 2009). Fungi are responsible for the biogeochemical cycle and the degradation of hazardous materials in the biosphere (Liang et al. 2005). The first report concerning chlorpyrifos bioremediation using chlorpyrifos hydrolase produced in C. cladosporioides was performed by Gao et al. (2012).

\section{Conclusion and future prospects}

Fungi are one of the most important groups of organisms on the planet, therefore, additional research to better characterise fungi should be performed. Recognised as an important and novel resource for natural bioactive products, fungi have potential applications in various domains such as medicine, the food industry and agriculture. Recently, research has been oriented towards investigating novel, natural bioactive products derived from fungi because of the declining discovery rate of active novel chemical entities. C. cladosporioides has been poorly studied despite its rich bioactive compound content, production of several enzymes and decreased risk compared with other extensively studied fungi. To date, there is scarce information regarding the bioactive compounds and secreted enzymes present in $C$. cladosporioides. However, studies that have been conducted on $C$. cladosporioides discovered bioactive compounds including p-methylbenzoic acid, EP and calphostin $\mathrm{C}$ as well as enzymes such as PME, PG and chlorpyrifos hydrolase.

p-Methylbenzoic acid stimulates the synthesis of 1,5benzodiazepine and its derivatives that possess beneficial human health effects. It also increases PET yield, which is used in synthetic fibres, beverage, food and liquid containers. p-Methylbenzoic acid enhances EPA production, which is present in membrane-bound organisms from bacteria to humans. EPA may also potentially be used in the clinical management of malignancy patients. Although EP has demonstrated anticancer, antiangiogenic, antibacterial, anti-oxidative and immunosuppressive properties, $C$. cladosporioides derived EP has not been studied against various types of diseases. Calphostin $\mathrm{C}$, a known anticancer agent, inhibits PKC by inactivating both $\mathrm{PKC}$-epsilon and PKC-alpha. Calphostin C induces apoptosis in WEHI-231 cells and VSMCs. Calphostin $\mathrm{C}$ has been evaluated as a potential photodynamic therapy agent because of its stimulation of ER stress in certain cancers. Methylesterase (PME) and PG are pectinase enzymes that have garnered attention because of their applications in the food processing industry and its critical role in plant physiology. Chlorpyrifos hydrolase has been demonstrated to efficiently degrade and eliminate chlorpyrifos from the environment.

In conclusion, the focus of future research should be (1) investigating the optimal growth conditions for $C$. cladosporioides to produce high yields of p-methylbenzoic acid, EP and calphostin $\mathrm{C}$ along with chlorpyrifos hydrolase enzymes; (2) examining $C$. cladosporioides derived 
EP as a bioactive product against diverse types of diseases; (3) examining the anticancer activity of calphostin $\mathrm{C}$ in vivo; (4) characterising and completely purifying (PME) and PG; (5) characterising the molecular biology of the chlorpyrifos hydrolase gene and its regulatory mechanisms; and (6) identifying novel compounds and enzymes and examining those which exhibit biotechnological properties for use in medical and industrial applications.

\section{Compliance with ethical standards}

Conflict of interest We declare that we have no conflict of interest.

Open Access This article is distributed under the terms of the Creative Commons Attribution 4.0 International License (http:// creativecommons.org/licenses/by/4.0/), which permits unrestricted use, distribution, and reproduction in any medium, provided you give appropriate credit to the original author(s) and the source, provide a link to the Creative Commons license, and indicate if changes were made.

\section{References}

Aasth AP, Navneet K, Anshu A, Pratima S, Dharma K (2013) 1,5 Benzodiazepines: overview of properties and synthetic aspects. Res J Chem Sci 3:90-103

Abdel-Baky N, Abdel-Salam A (2003) Natural incidence of Cladosporium spp. as a bio-control agent against whiteflies and aphids in Egypt. J Appl Entomol 127:228-235

Alkorta I, Garbisu C, Llama MJ, Serra JL (1998) Industrial applications of pectic enzymes: a review. Process Biochem 33:21-28

Amorim HV, Amorim VL (1977) Coffee enzymes and coffee quality. In: ACS Symposium Series American Chemical Society

Anwar S, Liaquat F, Khan QM, Khalid ZM, Iqbal S (2009) Biodegradation of chlorpyrifos and its hydrolysis product 3,5,6-trichloro-2-pyridinol by Bacillus pumilus strain C2A1. J Hazard Mater 168:400-405

Avallone S, Brillouet JM, Guyot B, Olguin E, Guiraud JP (2002) Involvement of pectolytic micro-organisms in coffee fermentation. Int J Food Sci Technol 37:191-198

Babcock T, Helton WS, Espat NJ (2000a) Eicosapentaenoic acid (EPA): an antiinflammatory $\omega-3$ fat with potential clinical applications. Nutrition 16:1116-1118

Babcock T, Helton WS, Espat NJ (2000b) Eicosapentaenoic acid (EPA): an antiinflammatory $\omega-3$ fat with potential clinical applications. Nutrition 16:s1116-s1118

Bastos SC, Pimenta CJ, Dias DR, Chalfoun SM, Angélico CL, Tavares LS (2013) Pectinases from a new strain of Cladosporium cladosporioides (Fres.) De Vries isolated from coffee bean. World J Agric Sci 9:167-172

Beck SA, Smith KL, Tisdale MJ (1991) Anticachectic and antitumor effect of eicosapentaenoic acid and its effect on protein turnover. Cancer Res 51:6089-6093

Bhagobaty RK, Joshi SR, Malik A (2006) Microbial degradation of organophosphorous pesticide: chlorpyrifos (mini-review). Internet J Microbiol 4:1-6

Bok JW, Lermer L, Chilton J, Klingeman HG, Towers GH (1999) Antitumor sterols from the mycelia of Cordyceps sinensis. Phytochemistry 51:891-898

Buescher R, Furmanski R (1978) Role of pectinesterase and polygalacturonase in the formation of woolliness in peaches. J Food Sci 43:264-266
Calin GA, Croce CM (2006) MicroRNA-cancer connection: the beginning of a new tale. Cancer Res 66:7390-7394

Carr J (1985) Tea, coffee and cocoa. Microbiol Fermented Foods 2:133-154

Chmura SJ, Nodzenski E, Weichselbaum RR, Quintans J (1996) Protein kinase $\mathrm{C}$ inhibition induces apoptosis and ceramide production through activation of a neutral sphingomyelinase. Cancer Res 56:2711-2714

Cochran RC, Kishiyama J, Aldous C, Carr WCJR, Pfeifer KF (1995) Chlorpyrifos: hazard assessment based on a review of the effects of short-term and long-term exposure in animals and humans. Food Chem Toxicol 33:165-172

De Gregorio A, Mandalari G, Arena N, Nucita F, Tripodo M, Lo Curto R (2002) SCP and crude pectinase production by slurrystate fermentation of lemon pulps. Bioresour Technol 83:89-94

De Hoog GS, Guého E, Masclaux F, Gerrits van den Ende AH, Kwon-Chung KJ, McGinnis MR (1995) Nutritional physiology and taxonomy of human-pathogenic Cladosporium-Xylohypha species. Med Mycol 33:339-347

De Hoog GS, Queiroz-Telles F, Haase G, Fernandez-Zeppenfeldt G, Attili Angelis D, Gerrits Van Den Ende AH, Matos T, PeltrocheLlacsahuanga H, Pizzirani-Kleiner AA, Rainer J, RichardYegres N, Vicente V, Yegres F (2000) Black fungi: clinical and pathogenic approaches. Med Mycol 38:243-250

Dixit S, Upadhyay SK, Singh H, Pandey B, Chandrashekar K, Verma PC (2013) Pectin methylesterase of Datura species, purification, and characterization from Datura stramonium and its application. Plant Signal Behav 8:1-8

Dixon D, Polak-Wyss A (1991) The medically important dematiaceous fungi and their identification. Mycoses 34:1-18

Fernández-González M, Ubeda J, Vasudevan T, Otero R, Briones A (2004) Evaluation of polygalacturonase activity in Saccharomyces cerevisiae wine strains. FEMS Microbiol Lett 237:261-266

Fujimoto H, Nakayama M, Nakayamay Yamazaki M (1994) Isolation and characterization of immunosuppressive components of three mushrooms, Pisolithus tinctorius, Microporus flabelliformis and Lenzites betulina. Chem Pharm Bull 42:694-697

Gallo ML, Seldes AM, Cabrera GM (2004) Antibiotic long-chain and $\alpha, \beta$-unsaturated aldehydes from the culture of the marine fungus Cladosporium sp. Biochem Syst Ecol 32:545-551

Gao Y, Chen S, Hu M, Hu Q, Luo J, Li Y (2012) Purification and characterization of a novel chlorpyrifos hydrolase from $\mathrm{Cla}$ dosporium cladosporioides $\mathrm{Hu}-01$. PLoS ONE 7:1-8

Giles GA, Bain DR (2001) Technology of plastics packaging for the consumer market. Packaging Technology, Sheffield

Gonzalez SL, Rosso ND (2011) Determination of pectin methylesterase activity in commercial pectinases and study of the inactivation kinetics through two potentiometric procedures. Food Sci Technol (Campinas) 31:412-417

Guyton KZ, Kensler TW, Posner GH (2003) Vitamin D and vitamin D analogs as cancer chemopreventive agents. Nutr Rev 61:227-238

Harms H, Schlosser D, Wick LY (2011) Untapped potential: exploiting fungi in bioremediation of hazardous chemicals. Nat Rev Microbiol 9:177-192

Herpin TF, Van Kirk KG, Salvino JM, Yu ST, Labaudinière RF (2000) Synthesis of a 10000 member 1,5-benzodiazepine-2-one library by the directed sorting method. J Comb Chem 2:513-521

Hoondal G, Tiwari R, Tewari R, Dahiya N, Beg Q (2002) Microbial alkaline pectinases and their industrial applications: a review. Appl Microbiol Biotechnol 59:409-418

Huong LM, Nghi DH, Ha TTH, Hang TN, Chi HK, Toan MN, Cuong NX, Kiem PV, Minh CV, Ullrich R, Hofrichter M (2010) Cytotoxic and antibacterial compounds from fermented broth of Phellinus adamantinus. J Chem 48:544-548 
Iconomou D, Arapoglou D, Israilides C (2010) Improvement of phenolic antioxidants and quality characteristics of virgin olive oil with the addition of enzymes and nitrogen during olive paste processing. Grasas Aceites 61:303-311

Inceoglu B, Wagner K, Schebb NH, Morisseau C, Jinks SL, Ulu A, Hegedus C, Rose T, Brosnan R, Hammocka BD (2011) Analgesia mediated by soluble epoxide hydrolase inhibitors is dependent on cAMP. Proc Natl Acad Sci 108:5093-5097

Jankauskaite V, Macijauskas G, Lygaitis R (2008) Polyethylene terephthalate waste recycling and application possibilities: a review. Mater Sci (Medžiagotyra) 14:119-127

Jayani RS, Saxena S, Gupta R (2005) Microbial pectinolytic enzymes: a review. Process Biochem 40:2931-2944

Johanning E (1999) Bioaerosols, fungi and mycotoxins: health effects, assessment, prevention and control. Fungal Research Group Foundation, New York

Kashyap D, Vohra P, Chopra S, Tewari R (2001) Applications of pectinases in the commercial sector: a review. Bioresour Technol $77: 215-227$

Kaul A, Maltese WA (2009) Killing of cancer cells by the photoactivatable protein kinase $\mathrm{C}$ inhibitor, calphostin $\mathrm{C}$, involves induction of endoplasmic reticulum stress. Neoplasia $11: 823-834$

Kawamoto J, Kurihara T, Yamamoto K, Nagayasu M, Tani Y, Mihara H, Hosokawa M, Baba T, Sato SB, Esaki N (2009) Eicosapentaenoic acid plays a beneficial role in membrane organization and cell division of a cold-adapted bacterium, Shewanella livingstonensis Ac10. J Bacteriol 191:632-640

Kluskens Ld, Van Alebeek GJW, Walther J, Voragen AG, De Vos WM, Van Der Oost J (2005) Characterization and mode of action of an exopolygalacturonase from the hyperthermophilic bacterium Thermotoga maritima. FEBS J 272:5464-5473

Kobayashi E, Nakano H, Morimoto M, Tamaoki T (1989) Calphostin $\mathrm{C}$ (UCN-1028C), a novel microbial compound, is a highly potent and specific inhibitor of protein kinase $\mathrm{C}$. Biochem Biophys Res Commun 159:548-553

Kobori M, Yoshida M, Ohnishi-Kameyama M, Shinmoto H (2007) Ergosterol peroxide from an edible mushroom suppresses inflammatory responses in RAW264. 7 macrophages and growth of HT29 colon adenocarcinoma cells. $\mathrm{Br}$ J Pharmacol 150:209-219

Krogh P (1989) The role of mycotoxins in disease of animals and man. J Appl Microbiol 67:99-104

Kumar R, Joshi Y (2007) Synthesis, spectral studies and biological activity of 3H-1,5-benzodiazepine derivatives. Arkivoc 13:142-149

Kuo Y, Weng S, Chou C, Chang T, Tsai W (2003) Activation and proliferation signals in primary human $\mathrm{T}$ lymphocytes inhibited by ergosterol peroxide isolated from Cordyceps cicadae. $\mathrm{Br} \mathrm{J}$ Pharmacol 140:895-906

Lee DY, Deng Z, Wang CH, Yang BB (2007) MicroRNA-378 promotes cell survival, tumor growth, and angiogenesis by targeting $\mathrm{SuFu}$ and Fus-1 expression. Proc Natl Acad Sci 104:20350-20355

Lee KY, Strand SE, Doty SL (2012) Phytoremediation of chlorpyrifos by populus and salix. Int J Phytoremediat 14:48-61

$\mathrm{Li} \mathrm{X}, \mathrm{He} \mathrm{J}, \mathrm{Li} \mathrm{S}$ (2007) Isolation of a chlorpyrifos-degrading bacterium, Sphingomonas sp. strain Dsp-2, and cloning of the mpd gene. Res Microbiol 158:143-149

Li J, Liu J, Shen W, Zhao X, Hou Y, Cao H, Cui Z (2010) Isolation and characterization of 3,5,6-trichloro-2-pyridinol-degrading Ralstonia sp. strain T6. Bioresour Technol 101:7479-7483

Liang WQ, Wang ZY, Li H, Wu PC, Hu JM, Luo N, Cao LX, Liu YH (2005) Purification and characterization of a novel pyrethroid hydrolase from Aspergillus niger ZD11. J Agric Food Chem 53:7415-7420
Liu B, Renaud C, Nelson KK, Chen YQ, Bazaz R, Kowynia J, Timar J, Diglio CA, Honn KV (1992) Protein-kinase-C inhibitor calphostin $\mathrm{C}$ reduces $\mathrm{B} 16$ amelanotic melanoma cell adhesion to endothelium and lung colonization. Int J Cancer 52:147-152

Macher J (1999) Bioaerosols: assessment and control. In: American Conference of Governmental Industrial Hygienists (ACGIH)

Manhiani M, Quigley JE, Knight SF, Tasoobshirazi S, Moore T, Brands MW, Hammock BD, Imig JD (2009) Soluble epoxide hydrolase gene deletion attenuates renal injury and inflammation with DOCA-salt hypertension. Am J Physiol Renal Physiol 297:740-748

Masclaux F, Guého E, De Hoog G, Christen R (1995) Phylogenetic relationships of human-pathogenic Cladosporium (Xylohypha) species inferred from partial LS rRNA sequences. Med Mycol 33:327-338

Micheli F (2001) Pectin methylesterases: cell wall enzymes with important roles in plant physiology. Trends Plant Sci 6:414-419

Nishida T, Orikasa Y, Ito Y, Yu R, Yamada A, Watanabe K (2006) Escherichia coli engineered to produce eicosapentaenoic acid becomes resistant against oxidative damages. FEBS Lett 580:2731-2735

Northwest coalition for alternatives to pesticides NCAP (2000) Insecticide factsheets. http://www.pesticide.org

Ogiwara T, Negishi T, Chik C, Ho A (1998) Differential effects of two protein kinase C inhibitors, calphostin C and Gö6976, on pineal cyclic nucleotide accumulation. J Neurochem 71:1405-1412

Okada K, Takizawa K, Maebayashi Y, Xi L, Campos-Takaki GM, Nishimura K, Miyaji M, Fukushima K (1996) Ubiquinone systems of the genus Cladosporium and morphologically similar taxa. FEMS Immunol Med Microbiol 16:39-43

Okuyama H, Orikasa Y, Nishida T, Watanabe K, Morita N (2007) Bacterial genes responsible for the biosynthesis of eicosapentaenoic and docosahexaenoic acids and their heterologous expression. Appl Environ Microbiol 73:665-670

Oliver G, Bolles H, Shurdut B (1999) Chlorpyrifos: probabilistic assessment of exposure and risk. Neurotoxicology 21:203-208

Otto B (2000) Mycotic diseases in fish. Mycoses 43:76-78

Ouattara HG, Reverchon S, Niamke SL, Nasser W (2010) Biochemical properties of pectate lyases produced by three different Bacillus strains isolated from fermenting cocoa beans and characterization of their cloned genes. Appl Environ Microbiol 76:5214-5220

Pasha KM, Anuradha P, Subbarao D (2013) Applications of pectinases in industrial sector. Int J Pure Appl Sci Technol 16:89-95

Prompiboon P, Bhumiratana A, Ruchirawat S, Boucias DG, Wiwa TC (2008) Isolation of ergosterol peroxide from Nomuraea rileyi infected larvae of tobacco cutworm. World J Microbiol Biotechnol 24:2909-2917

Rhee YH, Jeong SJ, Lee HJ, Lee HJ, Koh W, Jung JH, Kim SH, Hoon KS (2012) Inhibition of STAT3 signaling and induction of SHP1 mediate antiangiogenic and antitumor activities of ergosterol peroxide in U266 multiple myeloma cells. BMC Cancer 12:1-11

Ribeiro DS, Henrique S, Oliveira LS, Macedo GA, Fleuri LF (2010) Enzymes in juice processing: a review. Int J Food Sci Technol 45:635-641

Rotenberg SA, Huang MH, Zhu J, Su L, Riedel H (1995) Deletion analysis of protein kinase $\mathrm{C}$ inactivation by calphostin $\mathrm{C}$. Mol Carcinog 12:42-49

San-Martin A, Painemal K, Díaz Y, Martinez C, Rovirosa J (2005) Metabolites from the marine fungus Cladosporium cladosporioides. J Argent Chem Soc 93:247-251

Sarığlu K, Demir N, Acar J, Mutl UM (2001) The use of commercial pectinase in the fruit juice industry, part 2: determination of the kinetic behaviour of immobilized commercial pectinase. J Food Eng 47:271-274 
Schwan RF, Wheals AE (2004) The microbiology of cocoa fermentation and its role in chocolate quality. Crit Rev Food Sci Nutr 44:205-221

Serrat M, Bermúdez RC, Villa TG (2002) Production, purification, and characterization of a polygalacturonase from a new strain of Kluyveromyces marxianus isolated from coffee wet-processing wastewater. Appl Biochem Biotechnol 97:193-208

Shirasaka N, Hirai Y, Nakabayashi H, Yoshizumi H (2005) Effect of cyanocobalamin and p-toluic acid on the fatty acid composition of Schizochytrium limacinum (Thraustochytriaceae, Labyrinthulomycota). Mycoscience 46:358-363

Sieiro C, García-Fraga B, López-Seijas J, Da Silva AF, Villa TG (2012) Microbial pectic enzymes in the food and wine industry. In: Valdez B (ed) Food Industrial Processes - Methods and Equipment. InTech. doi:10.5772/33403. ISBN 978-953-307905-9

Silva CF, Schwan RF, Sousa Dias Ë, Wheals AE (2000) Microbial diversity during maturation and natural processing of coffee cherries of Coffea arabica in Brazil. Int $\mathrm{J}$ Food Microbiol 60:251-260

Silva CF, Batista LR, Abreu LM, Dias ES, Schwan RF (2008) Succession of bacterial and fungal communities during natural coffee (Coffea arabica) fermentation. Food Microbiol 25:951-957

Singh BK, Walker A, Morgan JAW, Wright DJ (2004) Biodegradation of chlorpyrifos by Enterobacter strain B-14 and its use in bioremediation of contaminated soils. Appl Environ Microbiol 70:4855-4863

Souza JV, Silva ÉS, Maia ML, Teixeira MF (2003) Screening of fungal strains for pectinolytic activity: endopolygalacturonase production by Peacilomyces clavisporus 2A.UMIDA.1. Process Biochem 39:455-458

Speight JG (1999) Ullmann's encyclopedia of industrial chemistry. Pet Sci Technol 17:445

Takei T, Yoshida M, Ohnishi-Kameyama M, Kobori M (2005) Ergosterol peroxide, an apoptosis-inducing component isolated from Sarcodon aspratus (Berk.) S. Ito. Biosci Biotechnol Biochem 69:212-215

Tasić S, Miladinović-Tasić N (2007) Cladosporium spp.-cause of opportunistic mycoses. Acta Facultatis Medicae Naissensis 24:15-19

Tsoleridis CA, Pozarentzi M, Mitkidou S, Stephanidou-Stephanatou J (2008) An experimental and theoretical study on the regioselectivity of successive bromination sites of 7,8dimethyl-2,4-diphenyl-3H-1,5-benzodiazepine. Efficient microwave assisted solventless synthesis of 4-phenyl-3H-1,5-benzodiazepines. Arkivoc 15:193-209

Vakili M, Fard MH (2010) Chemical recycling of poly ethylene terephthalate wastes. World Appl Sci J 8:839-846

Varala R, Enugala R, Adapa SR (2007) p-Nitrobenzoic acid promoted synthesis of 1,5-benzodiazepine derivatives. J Braz Chem Soc 18:291-296

Whitaker JR, Voragen AG, Wong DW (2003) Handbook of food enzymology. Marcel Dekker, New York

Wu J, Xu F, Zhou Z, Shen Q (2006) Efficient synthesis of 1,5benzodiazepine derivatives by ytterbium trichloride-catalyzed condensation of o-phenylenediamine and ketones. Synth Commun 36:457-464

Wu QP, Xie YZ, Deng Z, Li XM, Yang W, Jiao CW, Fang L, Li SZ, Pan HH, Yee AJ, Lee DY, Li C, Zhang Z, Guo J, Yang BB (2012) Ergosterol peroxide isolated from Ganoderma lucidum abolishes microRNA miR-378-mediated tumor cells on chemoresistance. PLoS ONE 7:1-14

Xu G, Zheng W, Li Y, Wang S, Zhang J, Yan Y (2008) Biodegradation of chlorpyrifos and 3,5,6-trichloro-2-pyridinol by a newly isolated Paracoccus sp. strain TRP. Int Biodeterior Biodegrad 62:51-56

Yaoita Y, Yoshihara Y, Kakuda R, Machida K, Kikuchi M (2002) New sterols from two edible mushrooms, Pleurotus eryngii and Panellus serotinus. Chem Pharm Bull 50:551-553

Yasukawa K, Aoki T, Takido M, Ikekawa T, Saito H, Matsuzawa T (1994) Inhibitory effects of ergosterol isolated from the edible mushroom Hypsizigus marmoreus on TPA-induced inflammatory ear oedema and tumour promotion in mice. Phytother Res 8:10-13

Yu YL, Fang H, Wang X, Wu XM, Shan M, Yu JQ (2006) Characterization of a fungal strain capable of degrading chlorpyrifos and its use in detoxification of the insecticide on vegetables. Biodegradation 17:487-494

Zheng XL, Gui Y, Du G, Frohman MA, Peng DQ (2004) Calphostin$\mathrm{C}$ induction of vascular smooth muscle cell apoptosis proceeds through phospholipase D and microtubule inhibition. J Biol Chem 279:7112-7118

Zheng T, Wang J, Chen X, Liu L (2010) Role of microRNA in anticancer drug resistance. Int J Cancer 126:2-10 